\title{
Comparison of two ketamine/xylazine anesthesic protocols in pigs (Sus scrofa domestica)
}

\section{Manuel Alejandro Guevara ${ }^{1}$, Sofía Ana Lorenzo Acquaro' ${ }^{1}$, Marcos Giai $^{1}$ and Pascual Angel Gargiulo ${ }^{1,2}$}

${ }^{1}$ Laboratorio de Neurociencias y Psicología Experimental. Área de Farmacología. Departamento de Patología. Facultad de Ciencias Médicas. Universidad Nacional de Cuyo. Consejo Nacional de Investigaciones Científicas y Técnicas (CONICET). República Argentina.

${ }^{2}$ Fundación Corporación Tecnológica Latinoamericana (FUCOTEL). Brandsen 2312. Dorrego (5519). Guaymallén. Mendoza. República Argentina. Email: pagargiulo@hotmail.com.

\begin{abstract}
The pig (Sus scrofa domestica) is an animal used as an experimental model in surgical procedures. This makes the use of anaesthesia necessary. The present study constitutes a comparison between two different ketamine/xylazine concentration protocols. One protocol used ketamine $10 \%+$ xylazine $10 \%$ (high concentration), and the other ketamine $5 \%+$ xylazine 2\% (low concentration). Concentrations were chosen since these are the most common presentations in the veterinary market. In the present experiments, twenty male and female pigs (Sus scrofa domestica; $20 \mathrm{~kg}$ each), were assigned into two different groups. The first one was integrated by pigs treated with high concentration protocol $(n=10)$, and the second one, composed by pigs that received low concentration protocol $(n=10)$. Parameters measured were the time in which the animals were placed in sternal decubitus, and the heart rate. The effects of these drugs were considered not only specifically in its sedative effects, but also in the respiratory system. Based on these results, we conclude that the first protocol showed better results than the second one. The time in which the animals were placed in sternal decubitus was lower in the first one $(p<0.001)$. Differences between the effects on the respiratory system $(p=0.37)$ and sedative effects $(p=0.87)$ were not significant, even when focusing on the last measurement, higher concentration protocol was twenty percent (20\%) more effective than lower.
\end{abstract}

Keywords: Ketamine; Xylazine; Sus scrofa domestica; Pig; Anaesthesia.
Received

December 18, 2018

Accepted

December 31, 2018

Released

December 31, 2018

Full Text Article

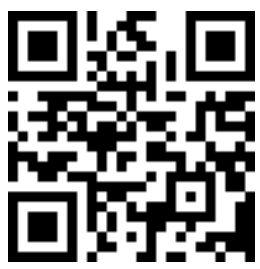

ORCID

(1) 0000-0001-5545-2037

Manuel Alejandro

Guevara

D) 0000-0002-8285-1196

Sofía Ana Lorenzo Acquaro

D) 0000-0003-3687-5645

Marcos Giai

(D) 0000-0003-2962-4346

Pascual Angel Gargiulo 


\section{Introduction}

In the last years, the porcine specimen (Sus scrofa domestica) has been chosen as an experimental animal model, due to the fact that it constitutes an interesting option in surgeries and infection diseases models (Meuren et al., 2012). The resemblance between body parameters of these animal and human beings support this decision. Vital signs such as heart rate $(100$ to 110 beats/min), respiratory frequency (15 to 20 breaths/min), blood pressure $(100 / 60 \mathrm{mmHg}+/-10 \mathrm{mmHg})$ and corporal temperature $\left(39^{\circ} \mathrm{C}+/-5^{\circ} \mathrm{C}\right)$ are considered here in the election of the species modelling surgical conditions (Clarence, 1988; González and Cruz, 2008). Moreover, the size of their organs is similar to the human ones (Walters et al. 2011).

Premedication is one of the most important parts in veterinary anaesthesiology, because this phase allows the professional not only to reduce the amount of necessary anaesthesia for induction and maintenance phases, but also to reduce and facilitate the necessary procedures, such as intravenous injections and endotracheal intubation. It is vital that premedication reaches its maximum effect as fast as possible, avoiding in this way stress, suffering, motor incoordination and traumatisms.

Ketamine is a phencyclidine derived, dissociative anaesthetic, NMDA receptor antagonist (Dominio et al., 1965). It was synthetized by Stevens in 1962 and introduced in human medicine by Corssen and Dominio (López-Millan et al., 2007). Nowadays, it is frequently used in veterinary Medicine (Guevara et al., 2016).

On the other hand, xylazine, an agonist at the $\alpha-2$ class adrenergic receptor (Flores, et al., 2000), was the first sedative and painkiller drug of its class used in veterinary medicine (Thurman et al., 1996).

The combination of these two drugs is widely used, not only in pigs, but also in different animal species (Guevara et al., 2017). In our laboratory, we use it in rats during stereotaxic surgery (Serrano et al., 2013).

The objective of this paper is to compare two ketamine/xylazine anesthesic protocols in pigs (Sus scrofa domestica).

\section{Materials and methods}

The experiments consisted mainly in a retrospective study of the anaesthetic registration forms. These experiments were made during 2010 and 2011 using pigs for teaching in the Experimental Surgery Institute, Faculty of Medical Sciences, National University of Cuyo (Universidad Nacional de Cuyo). Twenty three-month-old $\quad(\mathrm{n}=20)$ animals, $20(+/-2) \mathrm{kg}$ each, no race required, were used. After a $24 \mathrm{~h}$ solid foods period, pigs were anaesthetized according to the following procedures description. The animal's housing and experimental procedures were carried on following project approval criteria of the National University of Cuyo, accordingly to the guidelines set by European Community Council (Directive $86 / 609 /$ EEC), to the bioethical rules established by the Faculty of Medicine of the National University of Cuyo, and to Argentine law (Figure 1). 


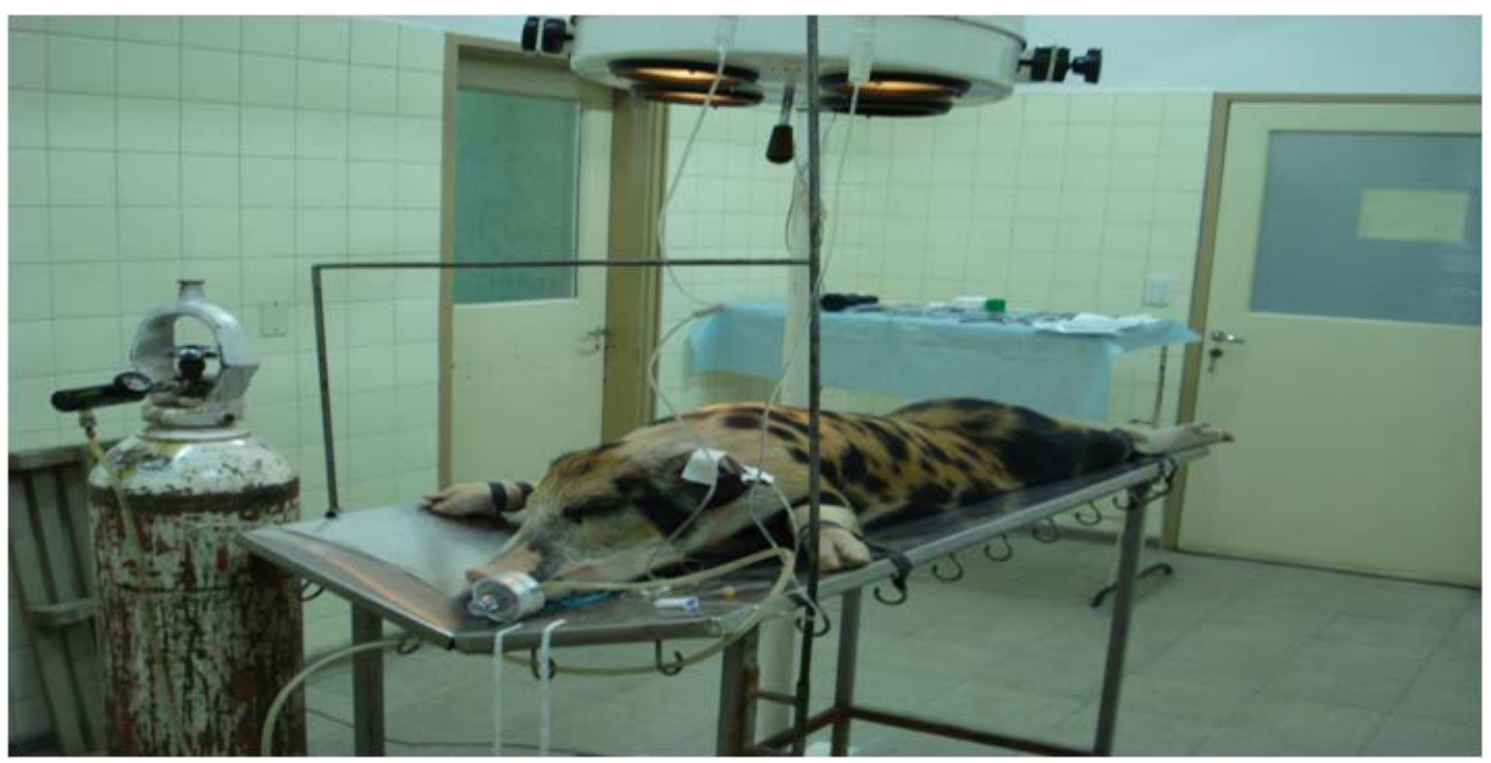

Figure 1. Pig under anaesthesia using the Ketamine 10\% + Xilazine 10\% protocol.

\section{Premedication}

The premedication was performed with ketamine $(10 \mathrm{mg} / \mathrm{kg})$ and xylazine $(2 \mathrm{mg} / \mathrm{kg})$. They were administered intramuscularly in semitendinous muscle. The animals were divided into two groups. One received the high concentration $(\mathrm{n}=10)$ and the other group $(n=10)$ received the lower one. An intravenous catheter was placed in a peripheral line (marginal vein of the ear).

\section{Anaesthetic induction}

Anesthetic induction was performed by intravenous drip with Fentanyl (3-5 g/kg), Midazolam $(1 \mathrm{mg} / \mathrm{kg})$ or Diazepam $(1 \mathrm{mg} / \mathrm{kg})$ and Propofol (2.5 to $5 \mathrm{mg} / \mathrm{kg}$ ), intravenously administered. An airway was established with an endotracheal tube. It was connected to an artificial respirator (respirator type "Takaoka"), for mechanical or assisted ventilation.

\footnotetext{
Maintenance

Maintenance was done with Fentanyl (3 to $5 \mathrm{~g} / \mathrm{kg} / \mathrm{h}$ ), Midazolam $(0.3 \mathrm{mg} / \mathrm{kg} / \mathrm{h})$ and Pancuronium $(0.1 \mathrm{mg} / \mathrm{kg}$, as a muscle relaxant).
}

\section{Surgical procedures}

The animals were maintained under anaesthesia and monitored for a period of approximately $4 \mathrm{~h}$. After it, they were euthanized with potassium chloride according to the method accepted in international standards for the use of experimental animals.

Animals were subjected to the following surgical procedures: canalization of jugular and femoral vein, peritoneal lavage, placement of thoracic drainage cardiac puncture and cricothyroidectomy.

It was evaluated after premedication the time in which the animal takes to be placed in decubitus, the heart rate at the time of placing in decubitus and the respiratory effect. Sternal decubitus time is a latency between application of anaesthesia and clinical effect. It is a measure of the time delay between the injection to the animal and the anaesthetic effect, when animal falls in sternal decubitus. It should be considered as a clinical index of full effect.

Severe apnea was considered when less than 20 breaths/min were found. Moderate apnea was considered when 20-60 breaths/min were verified. 
Mild apnea was considered when it was found more than 60 breaths $/ \mathrm{min}$. The sedative effect was studied using a scale from 1 to 3 points. One point was assigned when there were no voluntary movements or connection with the environment. It was given 2 points and was considered moderate when it was observed that there were involuntary movements but without connection with the environment. Finally, 3 points were applied and it was considered a slight grade when voluntary movements and connection to the environment were found.

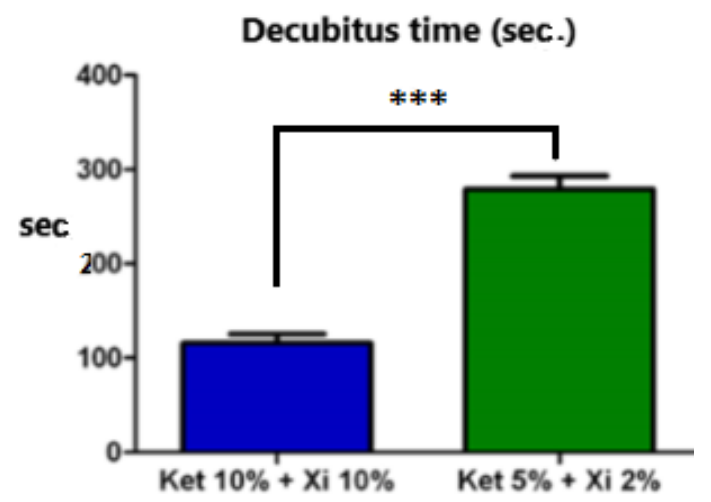

Figure 2. Decubitus time (s).

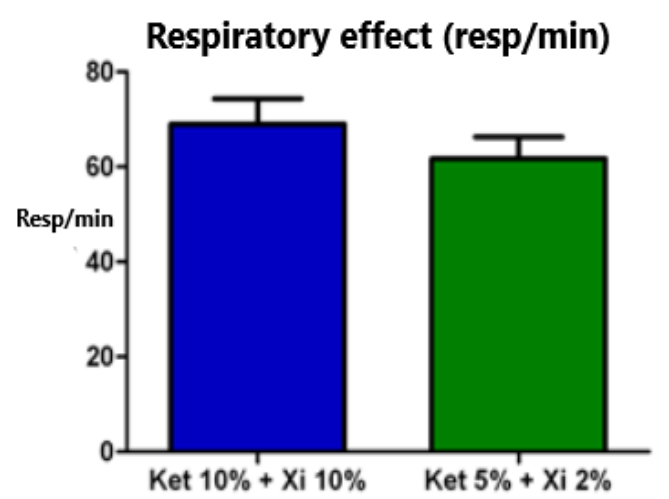

Figure 4. Respiratory effect.

\section{Results}

The higher dose anaesthetic protocol (ketamine 10\% + xylazine 10\%) led to better results when compared with the anaesthetic lower dose protocol (ketamine $5 \%+$ xylazine $2 \%$ ). The sternal decubitus time was significantly lower in the first protocol $(p<0.001$, Figure 2). No significant differences were observed when comparing respiratory frequency $(p=0.37$, Figure 3$)$ and sedative effect ( $p=0.87$, Figure 4$)$. There was not a significant effect on heart rate $(p=0.64$, Figure 5).

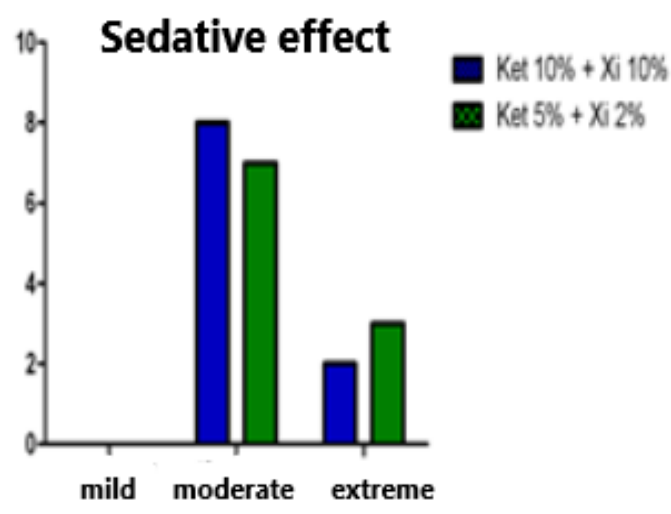

Figure 3. Sedative effect.

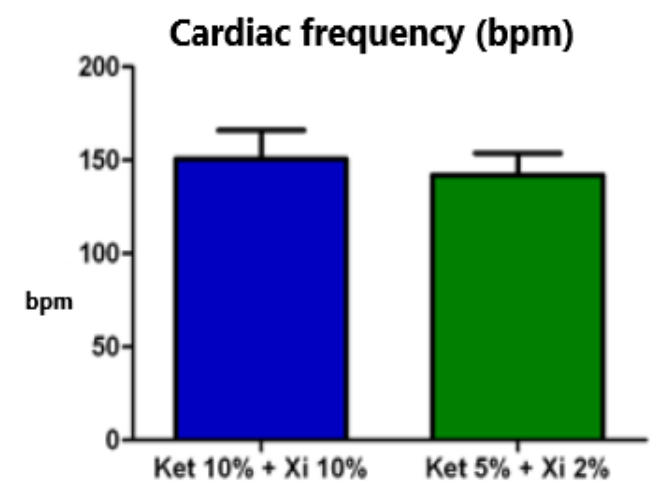

Figure 5. Cardiac frequency. 
Individual detailed parameters of the pigs used in the experiment [decubitus time (s), heart rate (sternal decubitus), respiratory frequency (breaths/min), and sedative effects]. Presentation of high (Table 1) and low concentration schedules (Table 2), and average results (Table 3).

Table 1. Description of the sex pig's group receiving Ketamine $10 \%$ and Xylazine $10 \%$. Weight (kg), decubitus time (s), heart rate (sternal decubitus), respiratory frequency (breaths/min) and sedative effects were considered.

\begin{tabular}{|l|c|c|c|c|c|}
\hline Sex & $\begin{array}{c}\text { Weight } \\
\text { (kg) }\end{array}$ & $\begin{array}{c}\text { Decubitus time } \\
\text { (s) }\end{array}$ & $\begin{array}{c}\text { Heart rate in } \\
\text { sternal Decubitus }\end{array}$ & $\begin{array}{c}\text { Respiratory } \\
\text { frecuency } \\
\text { Breaths/min }\end{array}$ & Sedative effect \\
\hline Male & 20 & 83 & 110 & 60 moderate & 1 severe \\
\hline Male & 25 & 120 & 270 & 102 mild & 2 moderate \\
\hline Male & 35 & 150 & 120 & 90 mild & 1 severe \\
\hline Male & 20 & 60 & 120 & 60 moderate & 1 severe \\
\hline Female & 25 & 120 & 180 & 42 moderate & 1 severe \\
\hline Female & 22 & 125 & 180 & 72 mild & 1 severe \\
\hline Female & 20 & 120 & 132 & 72 mild & 1 severe \\
\hline Female & 25 & 120 & 120 & 60 moderate & 2 moderate \\
\hline Female & 25 & 96 & 132 & 72 mild & 1 severe \\
\hline Female & 20 & 165 & 144 & 60 moderate & 1 severe \\
\hline Average & 23.7 & 115.9 & 150.1 & $\begin{array}{c}\text { Mild } 50 \% \\
\text { Moderate } 50 \% \\
\text { Severe } 0 \%\end{array}$ & $\begin{array}{c}\text { Mild } 0 \% \\
\text { Sederate } 20 \%\end{array}$ \\
\hline
\end{tabular}

Table 2. Description of the sex pig's group receiving Ketamine $5 \%$ and Xylazine $2 \%$. Weight $(\mathrm{kg})$, decubitus time (s), heart rate (sternal decubitus), respiratory frequency (breaths/min) and sedative effects were considered.

\begin{tabular}{|l|c|c|c|c|c|}
\hline Sex & $\begin{array}{c}\text { Weight } \\
\text { (kg) }\end{array}$ & $\begin{array}{c}\text { Decubitus time } \\
\text { (s) }\end{array}$ & $\begin{array}{c}\text { Heart rate } \\
\text { (sternal Decubitus) }\end{array}$ & $\begin{array}{c}\text { Respiratory } \\
\text { frecuency } \\
\text { (Breaths/min.) }\end{array}$ & Sedative effect \\
\hline Male & 20 & 300 & 180 & 60 moderate & 2 moderate \\
\hline Male & 20 & 300 & 200 & 42 moderate & 1 severe \\
\hline Male & 18 & 240 & 160 & 72 mild & 1 severe \\
\hline Male & 21 & 210 & 180 & 72 mild & 1 severe \\
\hline Female & 20 & 300 & 80 & 60 moderate & 1 severe \\
\hline Female & 19 & 240 & 140 & 60 moderate & 2 moderate \\
\hline Female & 20 & 300 & 160 & 90 mild & 1 severe \\
\hline Female & 20 & 240 & 160 & 60 moderate & 1 severe \\
\hline Female & 22 & 360 & 120 & 42 moderate & 2 moderate \\
\hline Female & 20 & 300 & 80 & 60 moderate & 2 moderate \\
\hline Average & 20 & 279 & 146 & $\begin{array}{c}\text { Mild 30\% } \\
\text { Moderate } 70 \%\end{array}$ & $\begin{array}{c}\text { Mild } 0 \% \\
\text { Soderate } 40 \% \\
\text { Seve } \% \%\end{array}$ \\
\hline
\end{tabular}


Table 3. Average results table.

\begin{tabular}{|c|c|c|c|}
\hline & $\begin{array}{c}\text { Ketamine } 10 \% \\
\text { Xylazine } 10 \% \\
(n=10)\end{array}$ & $\begin{array}{c}\text { Ketamine } 5 \% \\
\text { Xylazine } 2 \% \\
(n=10)\end{array}$ & \\
\hline Weight & 23.7 & 20.0 & \\
\hline Sex & $40 \%$ & $50 \%$ & \\
\hline Sternal Decubitus time (min) & 115.9 & 279.0 & $\mathrm{p}<0.001(\dagger)$ \\
\hline Sternal Decubitus heart rate (beats/min) & 150.1 & 142.0 & $p=0.64(\dagger)$ \\
\hline Respiratory frequency (breaths/min) & 69.0 & 61.8 & $\mathrm{p}=0.37(\dagger)$ \\
\hline Sedative effect (Index) & 1.2 & 1.3 & $\mathrm{p}=0.87(\&)$ \\
\hline
\end{tabular}

(†) Paired t Test; (\&) $X^{2}$ Test.

\section{Discussion}

As previously said, sternal decubitus time is a latency between application of anaesthesia and clinical effect. Sternal decubitus is the time delay between the moment of injection and the moment in which the animal falls in sternal decubitus. It may be considered a clinical index of full effect. The fact that maximal concentration here used led to a minimum latency may be considered as an efficacy related parameter. We may see here that higher doses significantly shortened sternal decubitus time.

Data obtained in present experiments showed a better effect using the higher concentrations schedule. It may be interpreted that most brain structures are abolished in its function with the higher schedule.

A partial blockade of some brain structures may lead to unexpected results. Actually, psychoses are today interpreted as an imbalance of brain structures (Grace, 2000; Gargiulo and Landa de Gargiulo, 2004, 2014). We have also observed that the selective blockade of several brain structures may lead to unexpected paradoxical results in the field of anxiolytic drugs (Llano López et al., 2013). Ketamine psychoses are observed below anaesthetic levels (Lahti et al., 1995; Blagrove et al., 2009), and dopaminergic alterations are supposed to be underling ketamine psychotogeniclike effects (Kokkinou et al., 2018).
We may speculate supposing that a low ketamine concentration in present results represents a subanaesthetic condition, with a high possibility of paradoxical results instead of anaesthetic effects. Maximal doses may lead to deeper anaesthesia states, excluding paradoxical effects since all brain structures are blocked. These findings led us to think that this effectiveness of the higher concentration schedule may be considered as derived of the action on the whole brain.

\section{Conclusions}

After all the information presented above, we conclude that the use of more concentrated drug schedule has more benefits, when compared with the use of more diluted ones.

\section{Acknowledgements}

We thank to the director of the Experimental Surgery Institute, Faculty of Medical Sciences, Universidad Nacional de Cuyo, Dr Eduardo Cassone and all his team. We thank Mrs. Patricia Grant de Gargiulo for her corrections as native speaker. We thank Mrs. Sara Roitman for her constant support.

\section{Conflict of interest}

Authors declare that they have no conflict of interests. 


\section{References}

Blagrove, M.; Morgan, C. J.; Curran, H. V.; Bromley, L.; Brandner, B. The incidence of unpleasant dreams after sub-anaesthetic ketamine. Psychopharmacology, v. 203, no. 1 , p. 109-120, 2009. https://doi.org/ 10.1007/s00213-008-1377-3

Clarence, F. El manual Merck. Madrid, España: Merck, 1988.

Dominio, E. F.; Chodoff, P.; Corssen, G. Pharmacologic effects of Ci-581, a new dissociative anesthetic, in man. Clinical Pharmacology \& Therapeutics, v. 6, no. 3, p. 279-291, 1965. https://doi.org/10.1002/ cpt196563279

Flores, E.; Cattaneo, G. Técnicas anestésicas inyectables de uso actual I. Premedicación y sedación. Monografías de Medicina Veterinaria, v. 20, no. 2, p. 34-48, 2000. Available from: <https://revistas.uchile.cl/ index.php/MMV/article/view/5016>.

Accessed on: May 23, 2018.

Gargiulo, P. A.; Landa de Gargiulo, A. I. Perception and psychoses: The role of glutamatergic transmission within the nucleus accumbens septi. Behavioural and Brain Sciences, v. 27, no. 6, p. 792-793, 2004. https://doi.org/10.1017/S0140525X 04270182

Gargiulo, P. A.; Landa de Gargiulo, A. I. Glutamate and modeling of schizophrenia symptoms: Review of our findings: 19902014. Pharmacological Reports, v. 66, no. 3, p. 343-352, 2014. https://doi.org/10.1016/ j.pharep.2014.03.010

González, A.; Cruz, Y. Técnicas clínicas: anestesia del cerdo en condiciones de hospital. Suis, no. 16, p. 46-49, 2008. Available from: <http://ivis.org/ advances/suis/A5513.1211.ES.pdf>.

Accessed on: May 23, 2018.

Grace, A. A. Gating of information flow within the limbic system and the pathophysiology of schizophrenia. Brain Research Reviews, v. $31, \quad$ n. $2 / 3, \quad$ p. 330-341, 2000. https://doi.org/10.1016/S0165-0173(99) 00049-1

Guevara, M.; Marquez Herrero, S.; Romanowic, E.; Hernánde, J.; García Menendez, S.; Gargiulo, P. The danger of the utilization of ketamine. Revista Veterinaria Argentina, v. 33, no. 340, p. 1-3, 2016. Available from: <https://www.veterinari argentina.com/revista/2016/08/el-peligro- del-consumo-de-ketamina/>. Accessed on: May 23, 2018.

Guevara, M.; Marquez Herrero, S.; García Menendez, S.; Baiardi, G.; Gargiulo, P. Incidencia de efectos adversos en perros $\mathrm{y}$ gatos con protocolos anestésicos compuestos por ketamina y xilazina (estudio preliminar). Proceeding of the XII Jornadas Cuyanas de Medicina Veterinaria, Mendoza, 11 y 12 de noviembre 2017.

Kokkinou, M.; Ashok, A. H.; Howes, O. D. The effects of ketamine on dopaminergic function: Meta-analysis and review of the implications for neuropsychiatric disorders. Molecular Psychiatry, v. 23, no. 1, p. 59-69, 2018. https://doi.org/10.1038/mp.2017.190

Lahti, A. C.; Koffel, B.; LaPorte, D.; Tamminga, C. A. Subanesthetic doses of ketamine stimulate psychosis in schizophrenia. Neuropsychopharmacology, v. 13, no. 1, p. 9-19, 1995. https://doi.org/10.1016/ 0893-133X(94)00131-I

Llano López, L. H.; Caif, F.; Fraile, M.; Tinnirello, B.; de Gargiulo, A. I.; Lafuente, J. V.; Baiardi, G. C.; Gargiulo, P. A. Differential behavioral profile induced by the injection of dipotassium chlorazepate within brain areas that project to the nucleus accumbens septi. Pharmacological Reports, v. 65, no. 3, p. 566-578, 2013. Available from: <http://www.if-pan.krakow.pl/pjp/pdf/ 2013/3_566.pdf>. Accessed on: May 23, 2018.

López-Millán, J.; Sánchez-Blanco, C. Utilización de ketamina en el tratamiento del dolor agudo y crónico. Revista de la Sociedad Española del Dolor, v. 14, no.1, p. 45-65, 2007. Available from: <http://scielo.isciii.es/pdf/dolor/v14n1/evi dencia.pdf>. Accessed on: May 23, 2018.

Meuren, F.; Summerfield, A.; Nauwynck, H.; Saif, L.; Gredts, V. The pig: A model for human infectious disease. Trends in Microbiology, v. 20, no. $1, \quad$ p. $50-57, \quad 2012$. https://doi.org/10.1016/j.tim.2011.11.002

Serrano, S.; Guevara, M.; Gargiulo, P. Técnica neuroquirúrgica de esterotaxia en ratas para colocación de cánulas intracerebrales. Revista Argentina de Neurología Veterinaria, v. 3, no. 1, p. 105-115, 2013. https://doi.org/10.1016/j.tim.2011.11.002

Thurman, J.; Tramquilli, W.; Benson, G. J. Lumb \& Jones' Veterinary Anesthesia. 3. ed. Baltimore, USA: Williams \& Wilkins, 1996. 
Walters, E.; Agca, Y.; Ganjam, V.; Evans, T. Animal Models got you puzzled?: Think pig. Annals of the New York Academy Science, v. $1245, \quad$ no. $1, \quad$ p. $63-64, \quad 2011$. https://doi.org/10.1111/j.1749-6632.2011. 06345.x

\footnotetext{
CC License information: This is an open-access article distributed under the terms of the Creative Commons Attribution License, which permits unrestricted use, distribution, and reproduction in any medium, provided the original work is properly cited.
} 